\title{
Analysis of the Implementation of Patient Safety Targets at the Makassar City Regional General Hospital
}

\author{
Andi Zulfaidah Putri Delima, ${ }^{1}$ Alimin Maidin ${ }^{1}$, Lalu Muhammad Saleh ${ }^{2}$ \\ ${ }^{1}$ Department of Hospital Management, Faculty of Public Health, Hasanuddin University, \\ Indonesia \\ ${ }^{2}$ Department of Occupational Health and Safety, Faculty of Public Health, Hasanuddin \\ University, Indonesia
}

Received: October 18, 2020

Revised: October 26, 2020

Accepted: October 28, 2020

\begin{abstract}
The Patient Safety Goals (SKP) drive specific improvements in patient safety. These objectives highlight problematic areas of health care in a system implemented in hospitals to make patient care safer. This study aims to analyze the implementation of patient safety goals in Makassar City Hospital. This type of research is mixed methods research. The research uses a sequential explanatory strategy. The results showed that the implementation of patient safety targets based on the Hospital Patient Safety Target Standards (SNARS) at Makassar City Hospital has a good implementation of patient safety targets. The implementation of patient safety targets in terms of leadership in the Makassar City Regional General Hospital (RSUD), namely the awarding of awards has never been done, and supervision is carried out by looking at patient safety reports. In terms of human resources, training related to patient safety is still lacking and only during accreditation. Regarding policies, there are SOPs related to patient safety incidents and there is no clear sanction, only a warning. For teamwork, there is no availability of a patient safety team in the treatment room, only KMKP has a patient safety team. In addition, the implementation of patient safety goals in terms of communication, namely the existence of positive feedback given and followed up by the Patient Safety and Quality Committee (KMKP), as well as lack of socialization by KMKP, only at the time of accreditation.
\end{abstract}

Keywords: Patient Safety, Human Resources, Policy, Teamwork, Communication

\section{Introduction}

Hospital patient safety (Patient Safety) is a system in which the hospital makes patient care safer. The system is a risk assessment, identification and management of matters related to patient risk, incident reporting and analysis, the ability to learn from incidents and their follow-up and implementation of solutions to minimize the incidence risk (Zulkani, 2017).

The implementation of patient safety practices can accelerate the healing process and shorten the patient's stay in the hospital and can prevent injury to patients. The successful implementation of patient safety can be achieved if employees know precisely something that threatens patient safety during hospitalization (Frankle, 2011).

In an effort to improve patient safety in hospitals, a patient safety standard was developed which refers to the Nine Life-Saving Patient Safety Solution from WHO which is also used by KKP-RS and JCI (Joint Commission International). One of the patient safety standards that have been set by JCI in 2011 is the target of implementing patient safety in hospitals or what is known as the National Patient Safety Goals for Hospital which includes identifying patients correctly, increasing effective communication, using medicines safely, ensuring the right

Copyright @ 2020, Journal of Asian Multicultural Research for Medical and Health Science Study, Under the license CC BY-SA 4.0 
location, procedure, and proper patient, lowering the risk of infection and identifying the risk of falls in the patient.

The Makassar City Regional General Hospital is one of the hospitals in Makassar City, South Sulawesi, which is a reference center for the northern gateway of Makassar and is also a public hospital with a class B status. The implementation of patient safety at the Makassar City Regional General Hospital is already underway since 2017 by establishing the Patient Safety Committee. The ongoing implementation of patient safety at the Makassar City Hospital has not been able to reduce the Patient Safety Incidence (IKP) at the hospital. This can be seen from the patient's safety incident data for the last three years, namely 2017-2019 which experienced fluctuation.

In the percentage of patient safety incidents in Unexpected Incidents (KTD), cases increased in 2018-2019, namely 18\%, patient safety incidents in Nearly Injury Incidents (KNC) experienced an increase in cases in 2018-2019 by 60\%, and safety incidents The most patients had Potential Injury Incidence (KPC) as much as 66\%. This shows that there are still many incidents of patient safety that occur in Makassar City Hospital and do not meet the standards set by the Ministry of Health No. 129 of 2008, namely zero incidents/cases.

There are many things that can cause or prevent patient safety incidents, one of which is increased effective communication, increased safety of drugs that need to be aware of (highalert), certainty of the right-location, right-procedure, the right patients who undergo actions and procedures, risk reduction healthcare-related infections and reduced risk of falling patients (Okuyama et al., 2018). In addition, leadership, human resources, policies, teamwork, and communication are also things that can cause or prevent incidents (Gilles, 2005). Patient safety incidents can be reduced or prevented by knowing the factors that contribute to patient safety incidents.

A study by Bardan et al (2017) based on an analysis of the application of patient safety at Inche Abdoel Moeis Regional Hospital by looking at factors such as leadership style, communication, and teamwork. In this case, in the leadership style in the form of direction, it is known that there is a reporting gap with management, so that management support is less than optimal by not immediately providing feedback on patient safety incident reports and imposing strict sanctions for employees who make mistakes related to the implementation of patient safety has never been carried out. Judging from the communication, namely the importance of patient safety, discussions are always carried out together and solutions are sought with the management so that the same problem does not occur again in the future. Whereas in teamwork, the employees really support the hospital in improving the program for implementing better patient safety because of the safety and comfort of the facilities and infrastructure that will be used by patients, which causes the application of patient safety to be not optimal at Inche Abdoel Moeis Hospital Samarinda.

Based on patient safety incident data at the Makassar City Regional General Hospital, opinions, and the results of the research of the figures described above, the researchers are interested in conducting research to analyze how the implementation of patient safety at the Makassar City Regional General Hospital by looking at the causes that have not been achieved accordingly. Kepmenkes standard No. 129 of 2008 regarding the incidence rate of $100 \%$ (zero incidences). This study aims to analyze the implementation of patient safety goals in Makassar City Hospital.

\section{Methods}

This type of research is mixed methods research. As for this study, researchers used a sequential explanatory strategy, namely in this strategy the first stage was collecting and

Copyright $@$ 2020, Journal of Asian Multicultural Research for Medical and Health Science Study, Under the license CC BY-SA 4.0 
analyzing quantitative data then followed by collection and analysis based on qualitative results. This research was conducted at the Makassar City Hospital in August - October 2020.

The population in this study for the quantitative method was surgical inpatients who received health services at the Makassar City Hospital. The sample of this research is 95 people. The sampling technique in this study was total sampling. The qualitative method consists of 10 informants whose selection technique uses purposive sampling.

The instrument used in data collection was a questionnaire. The questionnaire consisted of 26 question items regarding patient safety standards with a Cronbach's alpha value of 0.751 . Sources of data in this study are divided into two, namely primary data and secondary data. Primary data were obtained through in-depth interviews and observations of informants using interview guidelines. Secondary data were obtained from reviewing related documents that were used as supporting and complementary data from primary data for research purposes. The assistive instruments in this study were in-depth interview guidelines, observation guidelines, documentation tools, and notes in the field. Data analysis techniques are performed by reducing data, displaying data, transforming data, linking data, consolidating data, comparing data, and integrating data. Data presentation is presented in the form of brief descriptions, tables, and charts.

\section{Results and Discussion}

Table 1. Distribution of Respondents Based on the Implementation of Patient Safety Targets at the Makassar City Hospital

\begin{tabular}{|c|c|c|}
\hline $\begin{array}{c}\text { Implementation of Patient } \\
\text { Safety Goals }\end{array}$ & Amount & $\mathbf{( \% )}$ \\
\hline Good & $\mathbf{5 5}$ & $\mathbf{5 7 , 9}$ \\
\hline Bad & 40 & 42,1 \\
\hline Total & $\mathbf{9 5}$ & $\mathbf{1 0 0 , 0}$ \\
\hline
\end{tabular}

Table 1 shows the distribution of respondents regarding the implementation of patient safety targets at Makassar City Hospital. The implementation of patient safety targets at the Makassar City Hospital shows that as many as 55 respondents (57.9\%) have a good assessment of the implementation of patient safety goals and 40 respondents $(42.1 \%)$ have a bad assessment of the implementation of patient safety goals.

This study discusses the factors that influence patient safety incidents in the implementation of patient safety at Makassar City Hospital, namely factors of leadership, human resources, policies, teamwork, and communication.

Leadership as referred to in this research is the style of a leader who is able to become an agent of change for member behavior in an organization, namely direction, supervision, and coordination. Based on the interviews conducted regarding the awarding regarding patient safety, it was stated that there was no award regarding patient safety. Only in the form of a thank-you given regarding this matter.

Regarding the provision of freedom in giving opinions to subordinates regarding patient safety incidents, that there is freedom in giving opinions and there are no problems related to freedom of expression. Patient Safety and Quality Committee (KMKP) provides guidance and encouragement regarding patient safety incidents that KMKP only delivers to the head of the room and those who continue, meaning that KMKP does not directly provide guidance and encouragement and some also say that they have received this by KMKP. This was revealed from the following interview results: 
"Usually things are conveyed to the heads of the room, then the head of the room will continue" (Informant 5)

"Always give me motivation and guidance, in order to reduce the risk of accidents to patients, the same as how to properly implement patient safety" (Informant 3)

In addition, supervision by KMKP regarding the implementation of patient safety is known that KMKP is monitored regarding patient safety implementation, through reporting but not regularly. This was revealed from the following interview results:

"Supervision is always carried out, once a month from the report. From that report, we determine what the problem is, we go down to the unit" (Informant 1)

"Yes, it is done, but not regularly" (Informant 6)

Human resources referred to in this study are everything related to the quantity and quality of human resources in accordance with the work indicated by the policies that have been set and who are part of the patient safety committee regarding patient safety incidents. The results of the interviews related to the history of HR training, it was found that training related to patient safety had been carried out, but only at the time of accreditation. This was revealed from the following interview results:

"Yesterday, specifically for KMKP, there had been prior accreditation. Usually, it is the committee chairman who determines when, for example, needs to refresh his knowledge. It's just not 2020 yet, because considering the pandemic situation, then yesterday people worked shift shifts. So for 2020, it is not yet, but the previous years have been routinely implemented" (Informant 2)

"I said that yesterday, the time before the pandemic that wanted to be accredited yesterday was that. But now it's not there anymore, maybe focus first on the pandemic" (Informant 4)

The policy referred to in this research is the rules that apply in Makassar City Hospital which is a reference for creating safer conditions and preventing a dangerous incident in the hospital. At Makassar City Hospital, there are SOPs related to patient safety incidents and a reporting system. This is in accordance with the results of the document review, it is known that there are SOPs according to the types of incidents and there is an incident report form.

These SOPs include SOP for sentinel events, potential conditions of injury, unexpected events, procedures for reporting patient safety incidents, Root Cause Analysis (RCA) analysis, guidelines for implementing patient safety in hospitals, seven steps towards patient safety. hospitals, build awareness of patient safety culture, educate patients and their families about patient safety, and management of needles or sharp objects.

Regarding the availability of sanctions/penalties regarding patient safety incidents that there are no sanctions/penalties given, only in the form of a warning. This is so that they are not afraid to report when an incident occurs, and other informants claim that what was wrong is not the party who carried out the incident, but from the system. This was revealed from the following interview results:

"There is no mistake, at least the last point is the system" (Informant 1)

"Nothing, don't do it. You will return to the previous one, if for example you are given a sanction, you will be afraid to report it later" (Informant 5)

Teamwork referred to in this study is all forms that affect the process of collaboration between individuals in a team to treat patients at the Makassar City Hospital. Regarding the

Copyright (C) 2020, Journal of Asian Multicultural Research for Medical and Health Science Study, Under the license CC BY-SA 4.0 
availability of a patient safety team in the treatment room, that team once existed, but now it is unknown and only from the quality committee that has a patient safety team.

In addition, in relation to the cooperation between KMKP and other units, that cooperation with other units is in the form of problem-solving if an incident is reported and problemsolving is seen from the reports of each unit made, then resolved in a meeting.

The communication referred to in this research is an activity in interaction that involves behavior and allows individuals to relate to other people. Regarding positive feedback from reported events, it is known that most informants stated that there was positive feedback because when there was a problem, there was a follow-up for improvement. This was revealed from the following interview results:

"Yes, usually when I report directly, I will be told what the problem is or all kinds of things to do it regularly" (Informant 4)

"Yes, just as soon as there is a direct report" (Informant 5)

Based on interviews related to socialization by KMKP regarding patient safety incidents, it is known that most of the informants stated that socialization was carried out from KMKP in the form of meetings or to each room per unit. This was revealed from the following interview results:

"Always every month, ... a meeting to hold a socialization or to the room, as you go along" (Informant 1)

"If the socialization is yes, because the patient safety committee here joins the quality committee, after all, what is his name if he does quality socialization, that must be the socialization too, together" (Informant 4, 40 years)

Regarding the implementation of patient safety targets at the Makassar City Hospital, it is known that the implementation of the patient safety target program is going well. The application of patient safety targets patient identification, effective communication, drug, and fluid safety, the accuracy of patient-surgery location, reduction of infection risk, and fall prevention in the two Inpatient Rooms of Adi Husada Hospital Surabaya in good categories

The results of this study are not in line with research at the Lubuk Basung Regional Hospital which states that the patient safety program has not been well organized. This is due to limitations in its implementation, even though there is a written policy (Sum Transport et al., 2017).

Even though the implementation of patient safety goals is going well, it still needs improvement efforts such as fulfilling the facilities and infrastructure related to patient safety targets, carrying out re-socialization and patient safety training, and monitoring evaluation by the patient safety team which involves all staff in the hospital.

The leader has a duty as supervision. A supervisor must also be able to motivate employees to work and complete tasks, for example by giving praise or appreciation for what employees have done with good results and in accordance with what is expected. The award is one of the rewards given to motivate employees to have high productivity (Zulkani, 2017).

Regarding the awarding of awards by the hospital and the head of the installation itself for those who have performed well in achieving the standard number of patient safety incidents, employees at Makassar City Hospital have never been given an award for those who have good performance, only in the form of thanks. Even though they received gratitude, according to the informants, saying thank you was not a reward but they still had high motivation and enthusiasm to work well. 
The results of this study are in line with Febrianti (2017) that there are some nurses who feel that their rewards are not appropriate but still have good performance, this is because nurses feel there are no other options to work at the hospital and remember the difficulty of getting a job. The results of the study are not in line with that conducted by Isnainy \& Nugraha (2013) that one of the supporting factors in the successful performance of a health worker in a hospital is created if the hospital can provide rewards to each nurse according to their performance.

The statements above explain that appreciation is one of the basic needs of employees, apart from being a high work motivation, appreciation also means that the employee is considered to be in the company. With the award, employees will feel that their efforts in achieving are appreciated by the company, and this certainly spurs and motivates employees to contribute and achieve even better (Annisa et al., 2020).

Patient Safety and Quality Committee (KMKP) at Makassar City Hospital has provided guidance and encouragement regarding the implementation of patient safety and to reduce the number of patient accidents. Although it is not done regularly and evenly.

The results of this study are also in line with research conducted by Sihotang (2017) Doloksanggul General Hospital which examined the relationship of work motivation to the performance of nurses in providing services to patients. Based on the descriptive data, this study shows that the performance of nurses is in good categories and more states that increased motivation will increase the performance of nurses. Based on this, KMKP needs to play an active role in providing guidance and encouragement to each unit.

In addition, monitoring is always carried out by KMKP regarding the achievement of patient safety incidents by looking at patient safety data, if there is something that is problematic they immediately call the head of the installation or the head of the room concerned to explain the cause of the problem and to find a solution and not repeated for the same thing. Although, KMKP did not do this equally.

In accordance with the function of monitoring and controlling (controlling) which is carried out to assess the extent to which the work program that has been implemented is in accordance with patient safety standards. This monitoring and evaluation should be carried out regularly to find out what obstacles were encountered during the process. Monitoring and evaluation of the implementation of patient safety programs are very important to do. If the results are not as expected, then management can develop a positive work environment to ensure patient safety (Sulahyuningsih et al., 2017). In this case, it is necessary to carry out periodic supervision by the KMKP in each unit to find out the achievements or problems that have been caused related to patient safety incidents.

Makassar City Hospital, it is known that in terms of human resources in the patient safety committee, from the application of patient safety through the training that has been obtained, it is good enough because it has received training, but for now, it is not done because it is still in a pandemic period. Even though they had received training, this training was only obtained once by each informant and there was no regular training. This is related to Permenkes No. 11 of 2017 which says that education to staff about patient safety is an ongoing education and training activity to improve and maintain staff competence and support an interdisciplinary approach to inpatient care.

Training according to Henriksen (2002) and also Zulkani (2017) is a means of increasing the need for new knowledge and improving individual performance and system performance. So, to improve performance, it is necessary to carry out regular training. Patient safety education and training should be provided to all staff in the hospital. The Makassar City Hospital has

Copyright $@$ ( 2020, Journal of Asian Multicultural Research for Medical and Health Science Study, Under the license CC BY-SA 4.0 
programmed this, it's just that it has not been implemented for all officers or staff, it's just that the implementation is only at the head of the unit level.

One form of policy is the Standard Operating Procedures (SOP) which is one of the references in providing services or overcoming actions, especially regarding incidents or incidents in the hospital. SOP is a guideline designed to provide standards for every work performed by employees or members of an institution or organization as an effort to maximize the implementation of a predetermined policy (Wijaya \& Dewi, 2010).

In Makassar City Hospital, it is known that there are SOPs related to patient safety incidents and a reporting system, as well as an incident reporting form. Although there are some who still do not know about the availability of these SOPs, it is known that there is a lack of outreach from the patient safety committee to each unit regarding policies related to patient safety incidents, especially the reporting system. This also affects incident recording due to not knowing how the reporting system is in the hospital.

According to research conducted by Astuti (2018), the existence of SOPs can simplify the process of making decisions and adjust program responsibilities with existing resources and uniform actions of the implementers so that it is possible to adapt to the demands of change (Duany \& Duany, 2001; Kolström et al., 2011).

The existence of policies is also able to minimize the occurrence of errors by complying with existing policies. However, it does not mean that with a policy, there will be sanctions/penalties if they are not implemented according to the policy. In its implementation, sanctions are often the cause of controversy within the company, because some employees consider sanctions to be detrimental and unnatural because they do not spur work. They consider these sanctions as coercion (Zulkani, 2017).

At Makassar City Hospital, there are no sanctions/penalties available regarding patient safety incidents. Only given a warning, if there is something related to a patient safety incident. This is because if sanctions are given, the nurses will be more afraid to report and a blaming culture will occur.

Sanctions against mistakes should be used as valuable lessons and if necessary accompanied by sanctions in accordance with procedures to prevent the occurrence or recurrence of the same error (Harrington et al., 2004; Castle \& Ferguson, 2010). But this must be avoided with a blaming culture but as an effort to improve in an effort to improve patient safety.

Teamwork is one of the pillars of quality besides the scientific approach and continuous quality improvement in providing customer-focused services, including in efforts to improve patient safety (Bardan et al, 2017). At the Makassar City Hospital, there was a patient safety team in the treatment room, but now it is unknown to the informants. Apart from that, only the quality committee has a patient safety team.

To reduce the number of patient safety incidents, it is necessary to collaborate with every unit in the hospital. According to Baker et al in (Amirullah et al., 2014). Teamwork is needed among the medical team to improve patient safety by reducing errors due to teamwork between medical personnel.

Regarding the form of KMKP collaboration with other units in Makassar City Hospital in reducing patient safety incidents, it can be concluded that the form of cooperation carried out is in the form of handling problems if there are events or from reports of each unit that are made then resolved in meetings and making focus areas for problem handling. In this case, cooperation with KMKP is limited to reports made by the service unit at the hospital 
regarding patient safety incidents, not in terms of providing training or routine outreach, so the collaboration has not been going well.

This is in line with research conducted by Napitupulu et al (2017) regarding patient safety culture in terms of organizational aspects that the Hospital Patient Safety Team (TKPRS) has not communicated the results of follow-up patient safety incidents to all staff, simulations and training have not been provided to all. staff. Not yet providing information about the results of follow-up patient safety incidents to all staff at the hospital. In this case, the cooperation has not been going well.

Feedback in the communication process is a reply sent by the communicator to the communicator, after receiving a message from the communicator (Napitupulu et al., 2017) So as communicators, we will be able to immediately know whether the purpose of our message was conveyed or not. Regarding the positive feedback that is obtained if an incident is reported at the Makassar City Hospital, it is not always given and followed up by the patient safety committee. Feedback related to safety to the patient safety committee was felt to be good enough by the executive staff.

This is not in line with the research of Bardan et al (2017) in the Inche Abdoel Moeis Hospital, which states that management never gives feedback if there is a patient's incident reporting, and there is no follow-up on the report. In contrast to the results of Aris' research (2013) on the reciprocal dimensions of mistakes at PKU Muhammdiyah Hospital in good interpretation. This shows that if a medical error occurs, a good response will be given to the report. The error will be immediately searched for a solution. After the incident is over, it will be evaluated on the cases that occurred and ways to prevent these errors will not be repeated.

Communication must be conveyed clearly and accurately so that it is easy to understand and runs according to policy objectives. Of course, communication plays an important role in preventing the occurrence of various kinds of interpretations of every policy that has been issued, in order to be able to minimize the impact that may arise as a result of not having good communication between the message giver and the message recipient (Khaerah, 2018).

In Makassar City Hospital, it is known that there is still a lack of communication and socialization carried out by the KMKP regarding the reporting system and patient safety incidents at the hospital. The implementers of the policy, in this case, doctors, nurses, and medical staff, think that socialization has not been evenly distributed. This is due to the information delivery or socialization carried out regarding the reporting system and patient safety incidents only obtained by a few parties.

Based on the time of socialization, another informant stated that the socialization was only carried out when the hospital wanted accreditation. Although there are those who think that the socialization is not evenly distributed, KMKP itself thinks that KMKP has conducted socialization. It is recommended that socialization regarding the reporting system and patient safety incidents be carried out regularly to all teams starting from doctors, specialists, nurses, the nutrition team, and the pharmacy team.

In addition to socialization related to this, it is also necessary to socialize to each unit regarding the role of the patient safety committee so that all officers, especially health workers, know what the committee's job description, powers, and responsibilities are. Some informants, officers in each unit, as well as members of the patient safety committee themselves, do not know and do not understand the role of the patient safety committee, even not knowing the existence of this committee in the hospital. This is because there has not been any socialization regarding the role of the patient safety committee. 
This is in accordance with research (Sulahyuningsih et al., 2017) that the limitations in understanding and the mismatch of the role of the patient safety committee occur due to a lack of exposure to information. Education and training related to committee roles need to be carried out, so that committee managers understand and can carry out their roles according to their duties, responsibilities, and authorities.

\section{Conclusion}

Based on the results of the study, the researchers formulated the following conclusions: At Makassar City Hospital, the implementation of the patient safety target program was going well. Regarding leadership, giving awards and strict sanctions has never been carried out, and supervision is carried out by looking at patient safety reports. For human resources, training is still lacking, and only at the time of accreditation. Judging from the policy, SOPs have been available regarding patient safety incidents, but there has been no strict sanction given, only in the form of a warning. In addition, regarding teamwork, there is no availability of a patient safety team and the form of cooperation carried out is in handling problems through reports from each unit. In communication at the Makassar City Hospital, positive feedback is given and followed up by the KMKP, employees also report as soon as possible if they see anything that could threaten patient safety. In relation to the dissemination by KMKP, it was still lacking and only at the time of accreditation.

\section{References}

Kolström, M., Lindner, M., Vilén, T., Maroschek, M., Seidl, R., Lexer, M. J., ... \& Marchetti, M. (2011). Reviewing the science and implementation of climate change adaptation measures in European forestry. Forests, 2(4), 961-982.

Harrington, C., Mullan, J. T., \& Carrillo, H. (2004). State nursing home enforcement systems. Journal of Health Politics, Policy and Law, 29(1), 43-74.

Duany, J. A., \& Duany, W. (2001). War and women in the Sudan: Role change and adjustment to new responsibilities. Northeast African Studies, 8(2), 63-82.

Amirullah, N. A., Pasinringi, S. A., \& Kapalawi, I. (2014). Gambaran Budaya Keselamatan Pasien di RSUD Syekh Yusuf Kabuoaten Gowa. Repository Unhas, 1-16.

Wijaya, A. S., \& Dewi, A. (2015). Analisis Budaya Keselamatan Pasien Di RSU PKU Muhammadiyah, Bantul. JMMR (Jurnal Medicoeticolegal dan Manajemen Rumah Sakit), 4(1).

Henriksen, E. J. (2002). Invited review: Effects of acute exercise and exercise training on insulin resistance. Journal of applied physiology, 93(2), 788-796.

Aris. (2013). Analisis Budaya Keselamatan Pasien di RSU PKU Muhammadiyah. Thesis, Universitas Muhammadiyah Yogyakarta.

Astuti, R. W. (2018). Gambaran Pelaksanaan Clinical Pathway dari Perspektif Manajerial di RSUD Lasinrang Kabupaten Pinrang Tahun 2018. Thesis, Universitas Hasanuddin.

Bardan, R. J., Noor, N. B., \& Sangkala. (2017). Analisis Penerapan Keselamatan Pasien di Rumah Sakit Umum Daerah Inche Abdoel Moeis Tahun 2017. Thesis, Universitas Hasanuddin.

Frankle. (2011). Improving Patient Safety Across A Large Integrated Health Care Delivery System. International Journal Qual Health Care., 12(3).

Gilles. (2005). Manajemen Keperawatan Suatu Pendekatan Sistem, Edisi Terjemahan. Jakarta. 
Castle, N. G., \& Ferguson, J. C. (2010). What is nursing home quality and how is it measured?. The Gerontologist, 50(4), 426-442.

Khaerah, N. (2018). Studi Implementasi Clinical Pathway berdasarkan Perspektif Pelaksana di Rumah Sakit Umum Lasinrang Kabupaten Pinrang Tahun 2018. Thesis, Universitas Hasanuddin.

Napitupulu, H., Sudiro, \& Fatmasari, E. Y. (2017). Analisis Budaya Keselamatan Pasien Dengan Pendekatan Institute for Healthcare Improvement Ditinjau Dari Aspek Organisasi Di Rumah Sakit Jiwa Daerah Dr Amino Gondohutomo Semarang Tahun 2016. Jurnal Kesehatan Masyarakat (e-Journal), 5(1), 68-74.

Okuyama, J. H. H., Galvao, T. F., \& Silva, M. T. (2018). Healthcare professional's perception of patient safety measured by the hospital survey on patient safety culture: A systematic review and meta-analysis. Scientific World Journal, 2018. https://doi.org/10.1155/2018/9156301

Sulahyuningsih, E., Tamtomo, D. G., \& Joebagio, H. (2018). Analysis of Patient Safety Management in Committee for Quality Improvement and Patient Safety at Sumbawa Hospital, West Nusa Tenggara. Journal of Health Policy and Management, 2(2), 147-156.

Sumangkut, N. S. I., Kristanto, E., \& Pongoh, J. (2017). Evaluasi Penatalaksanaan Sasaran Keselamatan Pasien di Rumah Sakit Umum GMIM Kalooran Amurang. Community Health, 2(2), 56-73.

Zulkani, M. (2017). Analisis Penerapan Keselamatan Pasien dalam Insiden KTD dan KNC di Instalasi Laboratorium RSUD Inche Abdoel Moeis Samarinda Tahun 2017. Thesis, Universitas Hasanuddin.

Febrianti, A. (2017). Peran Perawat Dalam Perawatan Luka Diabetikum (Gangren) Di Ruang Dahlia Rumah Sakit TK II DR Ak Gani Palembang Tahun 2014. Masker Medika, 5(1), 42-78.

Isnainy, U. C. A. S., \& Nugraha, A. (2018). Pengaruh Reward dan Kepuasan Kerja Terhadap Motivasi Dan Kinerja Perawat. Holistik Jurnal Kesehatan, 12(4), 235-243.

Annisa, F., Maidin, A., \& Mangilep, A. U. A. (2020). Performance evaluation of patient safety committee in the regional general hospital of Makassar city. Enfermería Clínica, 30, 5-8. 